\title{
A case of ST elevation myocardial infarction immediately following OHT with a 28-year-old donor heart
}

\author{
Sadip Pant, Prafull Raheja, Rita Coram
}

Department of Cardiovascular Medicine, University of Louisville, Louisville, Kentucky, USA

\section{Correspondence to} Dr Sadip Pant, sadip.pant@louisville.edu

Accepted 5 September 2015

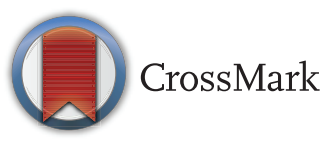

To cite: Pant $S$, Raheja $P$, Coram R. BMJ Case Rep Published online: [please include Day Month Year] doi:10.1136/bcr-2015210162

\section{DESCRIPTION}

A 55 -year-old man who received elective orthotopic heart transplantation with a 28-year-old donor heart was found to have ST elevation on the monitor, noticed by nursing staff on telemetry, the morning following surgery. A 12-lead ECG confirmed a current of injury in the anterior, apical, inferior and lateral leads (figure 1). The patient was taken immediately to the cardiac catheterisation laboratory for primary percutaneous coronary intervention (PCI). Coronary angiogram showed total thrombotic occlusion of mid left anterior descending (LAD) artery (video 1). Stenting of the mid LAD artery was necessary after four runs of aspiration thrombectomy and balloon angioplasty (POBA) of a residual moderate stenosis, with complete resolution of the stenosis and re-establishment of TIMI (thrombolysis in myocardial infarction) 3 flow (video 2). The patient subsequently had endomyocardial biopsy weekly as per protocol, which showed ISHLT (International Society for Heart and Lung Transplantation) Grade 0 for cellular rejection and negative antibody-mediated rejection. Echocardiogram showed ejection fraction of $45 \%$ with anterior and anteroseptal hypokinesis.

To the best of our knowledge, this is the first case of post-transplantation ST elevation myocardial infarction (STEMI) developing within $24 \mathrm{~h}$ of transplant with a young donor heart. The time frame of presentation and negative biopsy status make immune-mediated vasculopathy an unlikely mechanism for acute STEMI in this patient. The stress of the surgery most likely triggered decompensation of the mid-LAD plaque leading to STEMI. This case emphasises the need for screening younger donor hearts for coronary artery disease, especially those from donors with a history of smoking, as was the case here, and possibly the need for change in pretransplant screening guidelines in such high-risk young donors. The case also highlights the importance of keeping a high clinical

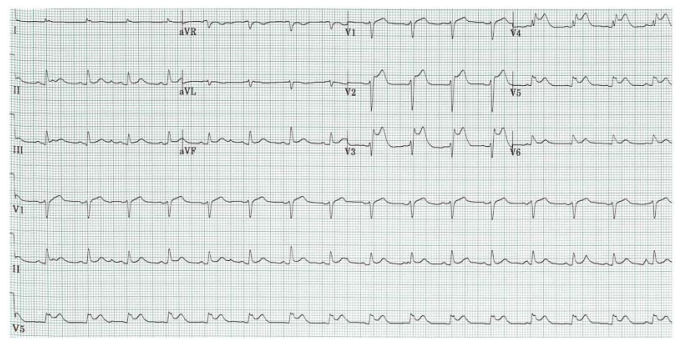

Figure 1 A 12-lead ECG confirmed a current of injury in anterior, apical, lateral and inferior leads.

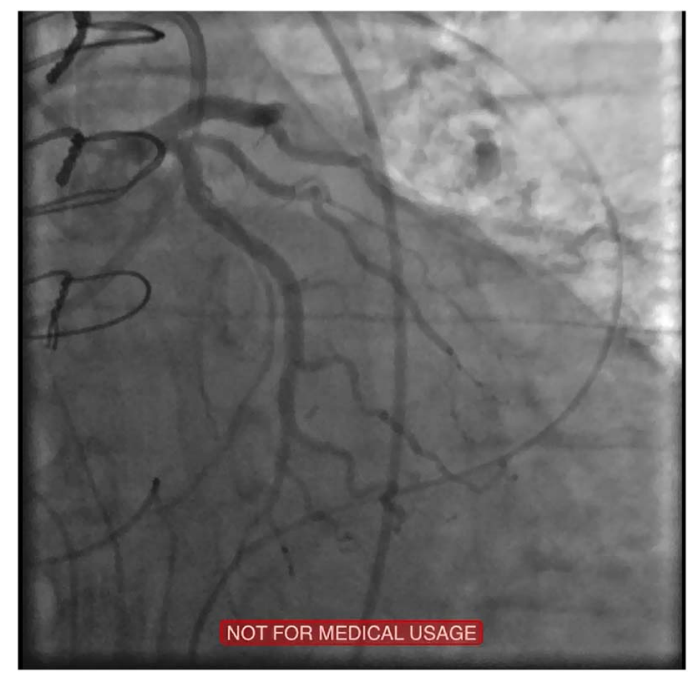

Video 1 Coronary angiogram showing a large calibre left anterior descending (LAD) with 100\% thrombotic occlusion immediately following the first septal perforator with TIMI (thrombolysis in myocardial infarction) 0 flow. The first diagonal branch was also involved in the thrombotic region. The left circumflex and right coronary artery were free of any significant disease.

suspicion for ischaemia in transplant recipients, as the presentation is not similar to that in patients with a normal heart. ${ }^{1}$

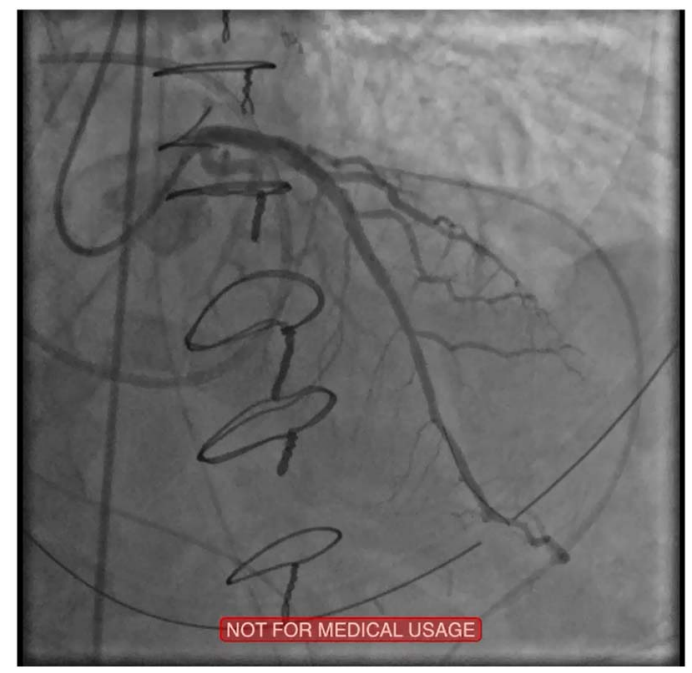

Video 2 Angiographic result following percutaneous coronary intervention $(\mathrm{PCI})$ on mid left anterior descending (LAD) with drug-eluting stent. TIMI (thrombolysis in myocardial infarction) 3 blood flow was established following the $\mathrm{PCI}$ to mid-LAD. 


\section{Learning points}

- Pretransplant screening for coronary disease needs to be individualised. Age does not necessarily exclude the need for screening.

- Not screening high-risk young donors may produce grave consequences for the recipient.

- Presentation of acute myocardial infarction in heart transplant recipients is not similar to that in patients with a normal heart; hence a high index of suspicion is needed to avoid missing the diagnosis in time.
Competing interests None declared.

Patient consent Obtained.

Provenance and peer review Not commissioned; externally peer reviewed.

\section{REFERENCE}

1 Peter S, Hulme O, Deuse T, et al. ST-elevation myocardial infarction following heart transplantation as an unusual presentation of coronary allograft vasculopathy: a case report. Transplant Proc 2013;45:787-91.

Copyright 2015 BMJ Publishing Group. All rights reserved. For permission to reuse any of this content visit http://group.bmj.com/group/rights-licensing/permissions.

BMJ Case Report Fellows may re-use this article for personal use and teaching without any further permission.

Become a Fellow of BMJ Case Reports today and you can:

- Submit as many cases as you like

- Enjoy fast sympathetic peer review and rapid publication of accepted articles

- Access all the published articles

- Re-use any of the published material for personal use and teaching without further permission

For information on Institutional Fellowships contact consortiasales@bmjgroup.com

Visit casereports.bmj.com for more articles like this and to become a Fellow 